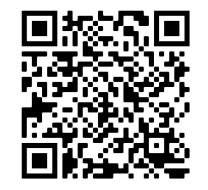

Keywords:

Forest succession

Secondary forests

Structural variables

Linear discriminant analysis

Received 30/06/2019

Accepted 13/05/2020

+Correspondence: framoncini.f@gmail.com
Fábio Fiamoncini Pastório ${ }^{\mathrm{la}+}$, André Luís de Gasper ${ }^{\mathrm{lb}}$, Alexander Christian Vibrans'

\section{SUCCESSIONAL STAGES OF SANTA CATARINA ATLANTIC SUBTROPICAL EVERGREEN RAINFOREST: A CLASSIFICATION METHOD PROPOSAL}

PASTÓRIO, F. F.; GASPER, A. L.; VIBRANS, A. C. B. Successional stages of santa catarina atlantic subtropical evergreen rainforest: a classification method proposal. CERNE, v. 26, n. 2, p. 162-171, 2020

\section{HIGHLIGHTS}

Current successional stages classification established by law presents inconsistencies.

A classification scheme proposed by researchers outperformed the current classification.

However, both schemes proposed by researchers are still subject to the same inconsistency.

A new classification scheme is proposed in order to resolve some of those issues.

\section{ABSTRACT}

In Santa Catarina State, forest classification in successional stages is supported by the National Council of the Environment (CONAMA) Resolution. However, this classification presents several inconsistencies. This study aimed to evaluate the classification accuracy of three classifications schemes of successional stages proposed for the Subtropical Atlantic Evergreen Rainforest of the Santa Catarina State. All schemes are based on threshold values of mean height, mean diameter at breast height, and basal area to distinguish between stages. We used structural and diversity data from 207 sample plots within the Santa Catarina's State Subtropical Rainforest region to classify the respective stands according to the schemes. The classification accuracy of each scheme was evaluated through the application of linear discriminant analysis (LDA). We constructed a predictive equation using the results of the LDA, from the scheme that presented highest classification accuracy. The current classification (CONAMA Resolution) showed an average of $81.87 \%$ of classification accuracy, while Scenario A presented $83.73 \%$ and Scenario B $78.67 \%$. From Scenario A, we created a predictive equation based on structural and diversity variables. This equation may be used to classify other forest sites, constituting a new proposal for the secondary vegetation classification in Santa Catarina's State Subtropical Rainforest. 


\section{INTRODUCTION}

The Atlantic Forest represents one of the most threatened Brazilian ecosystems due to the expansion of anthropic activities throughout the centuries (Dean, 1996; Scarano and Ceotto, 2015). More than $70 \%$ of the original forest cover has been devastated (Rezende et al., 2018), and the other remaining $30 \%$ are composed by secondary forests, mostly degraded landscapes with mostly small forest fragments (Ribeiro et al., 2009; Arroyo-Rodríguez et al., 2017). This scenario has triggered the emergence of important initiatives and public conservation policies in the last decades, such as the Atlantic Forest Restoration Pact in 2009 and the Atlantic Forest Law in 2006 (Calmon et al., 20 I I).

In this context, forest succession is a fundamental process in the reconstruction of plant communities and maintenance of biodiversity, consisting in one of the main theoretical bases present in conservation and forest recovery processes (Pickett et al., 1992; Prach and Walker, 20II; van Breugel et al., 20I3; Melo et al., 20I3). Thus, reliable categorization of secondary forests is a fundamental tool for management and restoration practices (Pickett et al., 2009; Peng et al., 2010; Prach and Walker, 20I I; Chazdon et al., 2016); furthermore, it enables the creation of a forest conservation policy in order to preserve forest patches in different successional stages (Chokkalingam and Jong, 200 I; Morse et al., 2009; Siminski et al., 20।3; Román-Dañobeytia et al., 20।4).

In the Brazilian Atlantic Forest, the Law nr. 11.428/2006, known as the Atlantic Forest Law (Brazil, 2006), and its further regulation (Brazil, 2008) established land use and management rules according to the successional stage of a given forest stand, with greater restrictions for stands at later stages. Herewith, to differentiate and define each successional stage (early, intermediate, and late), the variables considered by the Atlantic Forest Law are: i) structural (basal area, tree diameter at breast height $(\mathrm{DBH})$ and height), ii) physionomical (aspect, canopy cover, lifeforms, diversity and presence of epiphytes, lianas, litter and understory), (iii) floristic (indicator species) (Brazil, 2006).

In Santa Catarina State, the Resolution of the National Council of the Environment (CONAMA) nr. 04/94 (CONAMA, 1994), validated by Resolution nr. 388/07 (CONAMA, 2007), brings the classification established for its forests. Each successional stage is described by three quantitative and eight qualitative parameters, as described by the Atlantic Forest Law. This classification scheme has been criticized and its effectiveness has been questioned (Siminski et al.,
2004, 2013, Siminski and Fantini, 2004, 20I0; Andreacci and Marenzi, 2017). Inconsistencies associated with methodological issues were pointed out by these studies, as of: (i) lack of standardization regarding vegetation sampling, (ii) use of non-appropriate indicator species at each stage, and (iii) arbitrary established reference values and thresholds to differentiate the stages adequately. Furthermore, it is common that the three quantitative variables used by this classification may indicate different successional stages according to the analyzed variable, often generating conflicting results in the successional stage determination of a forest stand (Siminski et al., 20/3). In addition, the use of several qualitative parameters reflects a high subjective input in their determination on a field survey, since there is no threshold defined among categories. As forest management and land-use activities in private properties are partially determined by the size and conservation state of its vegetation (Brazil, 2006), uncertainties related to successional stage determination opens up a range of possible outcomes that may vary depending on who interprets them, being subject to individual's subjectivity or intentions in the decision-making process (Andreacci and Marenzi, 2017; Mota et al., 2019).

Accounting for these possible issues, Siminski et al. (2013) developed two alternative classification schemes for successional stage determination in Santa Catarina's subtropical evergreen rainforests. The first scheme (referred as Scenario A hereinafter) adopts the same proposal as the CONAMA classification, with the differential being the adjusted threshold values based on field surveys in areas of the state for the three quantitative parameters (basal area, $\mathrm{DBH}$ and height). As for the second scheme (referred as Scenario B hereinafter), the only parameters employed to differentiate each stage is basal area and height, with the definition of threshold values based on principles of ecological succession, as ecological attributes of the dominant species (Siminski et al., 2013). Although there are no mentions related to qualitative parameters in their schemes, the issue of possible divergent results among quantitative indicators remains present, as those variables are not mutually exclusive and can overlap to one another.

The process of objectively classifying and separating stages of succession in tropical rainforests is considered a challenge, and there is no ideal method for such a goal (Lu et al., 2003, Chazdon, 20 I4). Even adjacent areas with similar age, climate and soil conditions, may present multiple successional trajectories due to land use history and stochastic factors like seed dispersal (Chazdon et al., 2007; Norden et al., 2015). In the same way, land-use intensification (land-cover change, habitat 
fragmentation, and degradation), as well as non-native species interactions, may cause a regressive succession in forest remnants, known as biotic homogenization (Olden et al., 2004; Olden, 2006; Solar et al., 20I5).

Considering the adversities of the classification proposed by Resolution 04/94 and the difficulties regarding the effective discrimination between successional stages, this study aimed to propose a new classification method based on one of these three classification schemes: (i) the current valid scheme (Atlantic Forest Law and CONAMA Resolution 04/94), (ii and iii) schemes (Scenario $A$ and Scenario B) proposed by Siminski et al. (20I3). In order to choose one of these schemes, we evaluated the classification accuracy of each one obtained by linear discriminant analysis (LDA) applied to the same dataset. The dataset of the Floristic and Forest Inventory of Santa Catarina (IFFSC) presents an unprecedented opportunity to conduct rigorous comparisons of the classification accuracies: data independence, adequate sampling intensity, and broad geographical coverage and spatially unbiased data. Our hypothesis is that the CONAMA classification scheme will demonstrate lower accuracy in relation to the two other classification schemes. The new method corresponds to a predictive equation generated from the discriminant function of the scheme with highest classification accuracy, in order to overcome certain issues related to the current CONAMA classification scheme, as the possibility of controversial results.

\section{MATERIALS AND METHODS}

\section{Study area}

We studied the entire Subtropical Evergreen Rainforest area of Santa Catarina State in southern Brazil (referred hereinafter as Subtropical Rainforest; viz. Oliveira-Filho, 2009), located between the latitudes $25^{\circ} 57^{\prime} 40^{\prime \prime}$ and $29^{\circ} 19^{\prime} \mathrm{I} 3^{\prime \prime} \mathrm{S}$ and longitudes $48^{\circ} 24^{\prime}$ $21^{\prime \prime}$ and $50^{\circ} 14^{\prime}$ ' $14^{\prime \prime} \mathrm{W}$, with an area of $\sim 31,000 \mathrm{~km}^{2}$, of which $\sim 40 \%$ is forest land. The Floristic and Forest Inventory of Santa Catarina State (IFFSC) established 207 sample plots located at the intersections of a $10 \times 10$ $\mathrm{km}$ grid covering the entire area (Vibrans et al., 20l0). The sample plot consisted of a cluster of four crosswise subplots with an area of $1,000 \mathrm{~m}^{2}(20 \times 50 \mathrm{~m})$ each, located at $30 \mathrm{~m}$ from the sample plot center, covering an area of $\sim 2.6$ ha. Inside the sample plots' limits, all living trees, palms and tree ferns with diameter at breast height ( $\mathrm{dbh}) \geq 10 \mathrm{~cm}$ were identified and measured. The sample plots' altitude ranged approximately from 2 to I $200 \mathrm{~m}$ a.s.l. (Figure I). We refer to the sample plots as stands hereinafter.

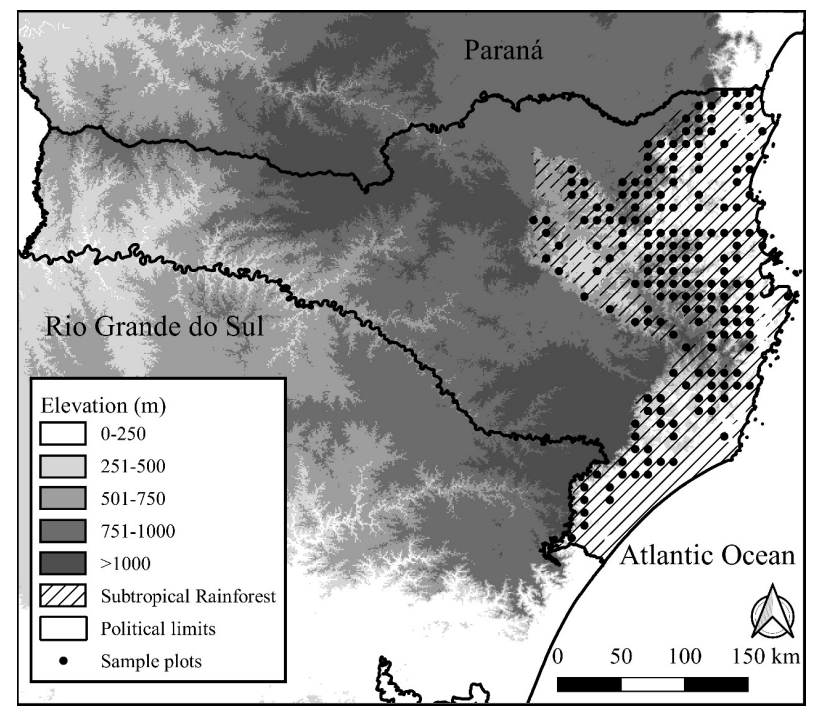

FIGURE I Sample plots (black dots) selected in this study, at the Subtropical Rainforest located at the eastern portion of Santa Catarina State, Brazil, established and inventoried by IFFSC (Vibrans et al., 20I0).

\section{Vegetation Classification}

We evaluated the classification accuracy of three classification schemes of secondary vegetation for the Subtropical Rainforest in Santa Catarina State: CONAMA Resolution 04/94 (CONAMA, 1994; referred to hereinafter as CONAMA) and the two schemes proposed by Siminski et al. (2013; referred to hereinafter as Scenario A and B). These three schemes allow us to classify secondary vegetation in early, intermediate and late stages, from the established reference values for three structural parameters measured in the field (Table I). Since different structural variables are used, these variables may indicate different stages for the same area, as found by Siminski et al. (20/3). In these cases, the successional stage in a stand were decided according to the majority of variables indicating the same stage. At Scenario B, with only two variables, we took basal area as the decisive variable, as it is commonly considered a reliable indicator variable in succession studies (Chazdon et al., 2007; Lebrija-Trejos et al., 20I I; Lohbeck et al., 20I4).

\section{Classification accuracy assessment: variable selection}

To begin with the accuracy assessment procedures, we selected several variables to represent the forest structure and diversity of our data set: absolute density (ind/ha- ${ }^{-1}$ ); absolute dominance $\left(\mathrm{m}^{2} / \mathrm{ha}^{-1}\right)$; mean DBH $(\mathrm{cm})$; asymptotic estimator of the effective number of species $\mathrm{q}=$ I (Shannon entropy index); proportion of pioneer individuals and proportion of pioneer species (\%, Table 2). The effective number of species, or Hill numbers (Chao et al., 20I4), is an 
TABLE I Secondary vegetation classification schemes for Subtropical Rainforest of Santa Catarina State and their structural variables used to distinguish between the early, intermediate and late stages of regeneration, as well as the number of IFFSC (Floristic and Forest Inventory of Santa Catarina State) stands classified at each stage according to each scheme.

\begin{tabular}{|c|c|c|c|c|c|}
\hline $\begin{array}{l}\text { Classification } \\
\text { System }\end{array}$ & $\begin{array}{l}\text { Stage of } \\
\text { Succession }\end{array}$ & $\begin{array}{c}\text { Basal Area } \\
\left(\mathrm{m}^{2} / \mathrm{ha}\right)\end{array}$ & $\begin{array}{l}\text { Mean } \\
\text { DBH } \\
(\mathrm{cm})\end{array}$ & $\begin{array}{c}\text { Mean } \\
\text { Height } \\
(\mathrm{m})\end{array}$ & $\begin{array}{c}\text { No. of } \\
\text { classified } \\
\text { IFFSC stands }\end{array}$ \\
\hline \multirow{3}{*}{ CONAMA } & Early & $\leq 8$ & $\leq 8$ & $\leq 4$ & 5 \\
\hline & Intermediate & $\leq 15$ & $\leq 15$ & $\leq 12$ & 43 \\
\hline & Late & $\leq 20$ & $\leq 25$ & $\leq 20$ & 159 \\
\hline \multirow{3}{*}{$\begin{array}{l}\text { Siminski et } \\
\text { al. }(2013) \text { - } \\
\text { Scenario A }\end{array}$} & Early & $\leq 5$ & $\leq 8$ & $\leq 6$ & 4 \\
\hline & Intermediate & 5 to 18 & 8 to 12 & 6 to 10 & 27 \\
\hline & Late & $\geq 18$ & $\geq 12$ & $\geq 10$ & 176 \\
\hline \multirow{3}{*}{$\begin{array}{l}\text { Siminski et } \\
\text { al. }(20 \text { I3) - } \\
\text { Scenário B }\end{array}$} & Early & $\leq 15$ & $\leq 10$ & - & 42 \\
\hline & Intermediate & 15 to 30 & 10 to 15 & - & 136 \\
\hline & Late & $\geq 30$ & $\geq 15$ & - & 29 \\
\hline
\end{tabular}

approach for quantification and extrapolation of species richness in biodiversity studies. The use of this approach has advantages over commonly used diversity indexes, since Hill's numbers ( $\mathrm{I}$ ) obey the principle of replication, (2) are expressed in effective species numbers (number of similarly abundant species necessary to correspond to the same value of a measure of diversity), and (3) are easily converted into diversity indexes such as Shannon and Simpson, making it possible to be directly compared to other studies (Chao et al., 2014). We chose the Hill number $\mathrm{q}=\mathrm{I}$ to represent the species richness, which corresponds to the exponential of the Shannon entropy index, considering the relative abundance of the species for the extrapolation of the species richness in each stand. The calculation of this estimator was performed in the $R$ environment ( $R$ Core Team, 20I8), using the "iNEXT" package (Hsieh et al., 20I6).

We performed a pre-selection of the structural and diversity variables to be used in the accuracy assessment analysis to reduce multicollinearity. For this, we used the Clustering of Variables method, by means of "ClustOfVar" package (Chavent et al., 20l2) in $R$ environment ( $R$ Core Team, 2018). Thus, four variables were selected: absolute density (AD); mean $\mathrm{DBH}$ (Mean.DBH); asymptotic estimator of the effective number of species $\mathrm{q}=\mathrm{I}$ (Shannon entropy index; AsyEst.Shannon); and proportion of pioneer individuals (Pioneer.ind). As these variables are expressed with different units of measure, all of them were standardized to z-scores (Zar, 20I0).

\section{Classification accuracy assessment: Linear Discriminant Analysis}

The accuracy assessment of the classification schemes was performed by means of the linear discriminant analysis (LDA). LDA is a multivariate statistical ordination technique, in which it seeks to find a linear combination of descriptive variables (discriminant function) from the maximization of variance between two or more pre-established groups of observations or samples, allowing the discrimination between these groups in a reduced dimensional space (Legendre and Legendre, 2012). The classification accuracy provided by the LDA results corresponds to the percentage of samples correctly reclassified by the discriminant function according to the pre-classification of the groups.

Analyzing groups with different numerical ratios (such as 10:90 or 25:75; Table 2) can significantly impair the discriminant potential of LDA, with higher probability of samples being reclassified within the larger group, and less likely to be classified in the smaller group (Holden et al., 20II; Bolin and Finch, 20I4). Thus, we excluded four stands classified in the early stage by CONAMA and Scenario $A$ schemes of the performance analysis and focused our analysis on the discrimination between the intermediate and late stages. To standardize the size of these two groups in the LDA, among the 203 stands, we randomly selected 25 stands classified in each of

TABLE 2 Means, minimum and maximum values of the structural and diversity variables calculated for the 207 IFFSC stands, by stage of secondary succession (early, intermediate and late) and old-growth forests classified in field surveys by IFFSC biologists (Vibrans et al., 2013). Legend: Asynthotic Shannon Estimator = asymptotic estimator of the effective number of species $q$ $=\mathrm{I}$ (Shannon entropy index).

\begin{tabular}{|c|c|c|c|c|c|c|c|c|c|c|c|c|}
\hline & \multicolumn{3}{|c|}{ Early Stage } & \multicolumn{3}{|c|}{ Intermediate Stage } & \multicolumn{3}{|c|}{ Late Stage } & \multicolumn{3}{|c|}{ Old-Growth Forests } \\
\hline & Mean & Min. & Máx. & Mean & Min. & Máx. & Mean & Min. & Máx. & Mean & Min. & Máx. \\
\hline Absolute Density (ind/ha- ${ }^{-1}$ ) & 149,49 & 31,84 & 358,82 & 590,08 & 350 & 995 & 691,43 & 257,50 & 1405 & 813,75 & 587,50 & 1095 \\
\hline Absolute Dominance $\left(\mathrm{m}^{2} / \mathrm{ha}^{-1}\right)$ & 7,37 & 2,46 & 9,53 & 16,73 & 10,29 & 27,04 & 26,15 & 14,13 & 47,82 & 32,17 & 22,98 & 49,81 \\
\hline Asymptotic Shannon Estimator & 16,97 & 6,98 & 32,97 & 33,08 & $|2,4|$ & 70,03 & 42,04 & 7,35 & 85,15 & 42,17 & 26,92 & 56,84 \\
\hline Mean DBH $(\mathrm{cm})$ & 17,16 & 14,15 & 19,78 & 16,82 & 13,80 & 24,06 & 19,24 & 14,94 & 26,90 & 19,29 & 14,59 & 24,34 \\
\hline Mean Height $(\mathrm{m})$ & 8,65 & 5,93 & 11,37 & 10,44 & 6,72 & 14,14 & $|I, 6|$ & 8,48 & 14,52 & 10,28 & 7,51 & 11,94 \\
\hline Proportion of pioneer individuals & $33 \%$ & $11 \%$ & $70 \%$ & $27 \%$ & $9 \%$ & $55 \%$ & $19 \%$ & $6 \%$ & $58 \%$ & $18 \%$ & $7 \%$ & $36 \%$ \\
\hline Proportion of pioneer species & $33 \%$ & $18 \%$ & $53 \%$ & $28 \%$ & $13 \%$ & $47 \%$ & $22 \%$ & $11 \%$ & $40 \%$ & $14 \%$ & $13 \%$ & $15 \%$ \\
\hline
\end{tabular}


these stages, for each classification scheme. Therefore, for each scheme, we carried out fifteen (I5) LDA, each time performing the randomization of the chosen stands, within the total set of stands. Each LDA generated a classification accuracy, totaling fifteen accuracy values for each scheme. The average of the fifteen accuracies were then determined and attributed to each scheme,. All the LDA runs were performed using the XLSTAT $2019 \mathrm{v}$. I.2 (Addinsoft, 2019) for the Microsoft Excel software. In all these analyses, the structural and diversity variables were standardized.

New Classification Proposal: predictive equation construction

Finally, the scheme with the highest mean classification accuracy was chosen to generate a predictive equation that allows to classify other secondary forest stands. The equation was constructed from the extraction of the canonical coefficients relative to the original variables of the discriminant function that most contributed to groups segregation, provided as a result of the LDA. This equation is referred to as classification function (Legendre and Legendre, 20I2). We chose the canonical coefficients of the discriminant function generated by the LDA that showed the highest classification accuracy among the three accuracies obtained.

In addition, we tested this equation in eight stands classified in the early stage by IFFSC field crews, in an attempt to determine a threshold between the early and intermediate stages of succession, since we did not include early stage stands in the LDA. To establish this threshold, we calculated the mean of the eight values obtained by the equation for the early stage stands, corresponding to an average value for this group. Subsequently, we calculated the mean value between this average value and the centroid obtained by the discriminant function for the intermediate stage (of the same LDA that the equation is based), therefore corresponding to the limit value between the early and intermediate stages of succession, given by the equation.

\section{RESULTS}

\section{Accuracy assessment (LDA)}

The CONAMA classification scheme presented a mean accuracy of $81.87 \%$ of correctly reclassified stands (Table 3 ). Scenarios A and B revealed a mean accuracy of $83.73 \%$ and $78.67 \%$, respectively (Figure 2 ).

The eigenvalues of the discriminant function (FI) from each LDA varied between 2.160 and 0.790 (CONAMA), 2.344 and 0.850 (Scenario A) and I.294
TABLE 3 Classification accuracies obtained for each LDA, separated by classification scheme, with the accuracies mean of each scheme. The highest accuracy percentage value obtained per scheme is highlighted in bold.

\begin{tabular}{|c|c|c|c|}
\hline \multirow[b]{2}{*}{ Nr. of LDA run } & \multicolumn{3}{|c|}{ Classification scheme } \\
\hline & CONAMA & Scenario A & Scenario B \\
\hline 1 & $90.00 \%$ & $86.00 \%$ & $90.00 \%$ \\
\hline 2 & $92.00 \%$ & $96.00 \%$ & $80.00 \%$ \\
\hline 3 & $86.00 \%$ & $90.00 \%$ & $86.00 \%$ \\
\hline 4 & $84.00 \%$ & $76.00 \%$ & $84.00 \%$ \\
\hline 5 & $90.00 \%$ & $84.00 \%$ & $74.00 \%$ \\
\hline 6 & $84.00 \%$ & $76.00 \%$ & $70.00 \%$ \\
\hline 7 & $80.00 \%$ & $84.00 \%$ & $80.00 \%$ \\
\hline 8 & $74.00 \%$ & $80.00 \%$ & $88.00 \%$ \\
\hline 9 & $72.00 \%$ & $88.00 \%$ & $74.00 \%$ \\
\hline 10 & $86.00 \%$ & $80.00 \%$ & $82.00 \%$ \\
\hline 11 & $76.00 \%$ & $76.00 \%$ & $76.00 \%$ \\
\hline 12 & $76.00 \%$ & $82.00 \%$ & $80.00 \%$ \\
\hline 13 & $78.00 \%$ & $90.00 \%$ & $70.00 \%$ \\
\hline 14 & $88.00 \%$ & $86.00 \%$ & $74.00 \%$ \\
\hline 15 & $72.00 \%$ & $82.00 \%$ & $72.00 \%$ \\
\hline $\begin{array}{c}\text { Classification } \\
\text { accuracies mean }\end{array}$ & $81.87 \%$ & $83.73 \%$ & $78.67 \%$ \\
\hline
\end{tabular}

and 0.478 (Scenario B). We observed in later stage group higher values of mean $\mathrm{DBH}$, absolute density and estimated species richness, and lower values of proportion of pioneer individuals, when compared to intermediate stage. Mean DBH variable stood out with greater contribution in most of LDA runs (Table 4). As Scenario A obtained the highest mean of classification accuracy, we selected it for the construction of the predictive equation of successional stages, using the canonical coefficients of the variables used in the discriminant function of the second LDA performed for this scheme (Scenario A (2)).

\section{New classification proposal}

By extracting the canonical coefficients of $\mathrm{FI}$ from Scenario A (2), we obtained the predictive equation (I). In addition, we provided the threshold values of $Y$ that separate each successional stage (Table 5). We computed a threshold value between early and intermediate stages from the mean between the $Y$ values of the early stage stands and the centroid function of the intermediate stage (Table 6). Thus, new observations within the Subtropical Rainforest of Santa Catarina State with these variables can be submitted to the equation and have their successional stage determined by the $Y$ value found, including the three stages of succession (early, intermediate and late). 


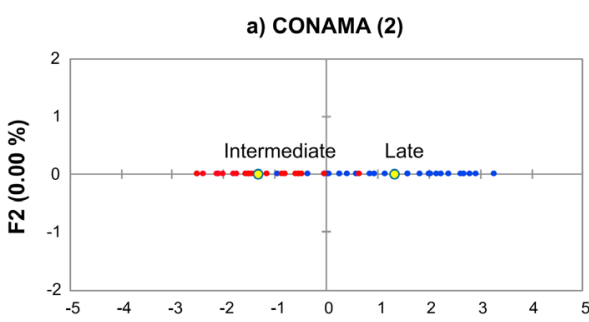

b) Siminski A (2)

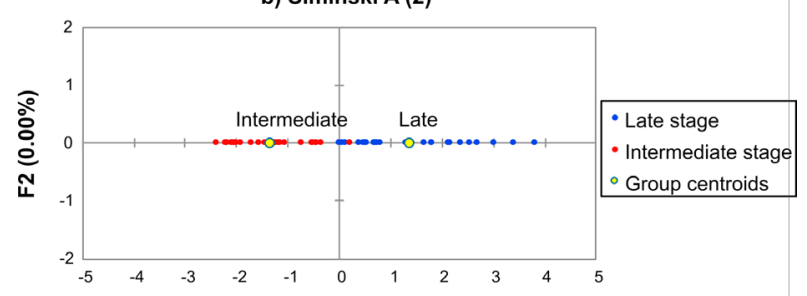

c) Siminski B (1)

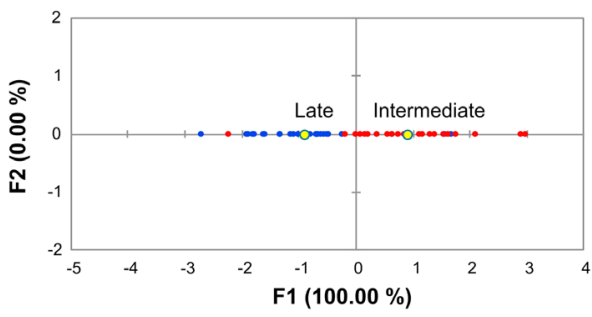

FIGURE 2 Ordination of the most accurate LDA based on: a) CONAMA (2); b) Scenario A (2); c) Scenario B (I). The dots represent the stands and their successional stage classification identified by red (intermediate stage) and blue (late stage) colors. Values in parentheses are the percentage of variance captured by the discriminant function.

TABLE 4 Pearson correlation ( $r$ ) of the variables with the discriminant functions (FI) resulting from the three most accurate LDA of each scheme. Values in parenthesis in the first column corresponds to the number of LDA run. Legends: $D f=$ discriminant function; $A D=$ absolute density; AsyEst.Shannon = asymptotic estimator of the effective number of species $\mathrm{q}$ $=\mathrm{I}$ (Shannon entropy index); Mean.DBH $=$ mean $\mathrm{DBH}$; Pioneers.ind = proportion of pioneer individuals.

\begin{tabular}{cccccc}
\hline System & Df & AD & $\begin{array}{c}\text { AsyEst. } \\
\text { Shannon }\end{array}$ & $\begin{array}{c}\text { Mean. } \\
\text { DBH }\end{array}$ & Pioneers.ind \\
\hline CONAMA (I) & FI & -0.732 & -0.602 & -0.630 & 0.690 \\
\hline CONAMA (2) & FI & 0.488 & $0.36 I$ & 0.872 & -0.670 \\
\hline CONAMA (5) & FI & $-0,326$ & $-0,733$ & $-0,929$ & $0,74 I$ \\
\hline Scenario A (2) & FI & 0.485 & 0.379 & 0.860 & -0.555 \\
\hline Scenario A (3) & FI & -0.453 & -0.397 & -0.800 & 0.393 \\
\hline Scenario A (I3) & FI & $-0,445$ & $-0,364$ & $-0,813$ & 0,498 \\
\hline Scenario B (I) & FI & -0.143 & -0.195 & -0.790 & 0.664 \\
\hline Scenario B (3) & FI & 0.100 & 0.426 & 0.852 & -0.495 \\
\hline Scenario B (8) & FI & 0,440 & 0,077 & $0,7 I I$ & $-0,452$ \\
\hline
\end{tabular}

$Y=(0.864 . A D)+(-0.275 \cdot$ AsyEst.Shannon $)+(1.533$. Mean. $D B H)+$

$(-0.099$. Pioneers.ind $)$

TABLE 5 Y values delimiting intermediate and late successional stages, and the centroid functions of each group, according to the predictive equation (I).

\begin{tabular}{ccc}
\hline Stage & Y Value & Group function centroid \\
\hline Intermediate & $Y<0$ & -1.353 \\
\hline Late & $Y>0$ & 1.353 \\
\hline
\end{tabular}

TABLE 6 Mean value between the Y-mean of the early stage stands and the centroid function of the intermediate stage, corresponding to the estimated threshold value between the early and intermediate stages of succession.

\begin{tabular}{cc}
\hline & Value \\
\hline Mean Y (early stage) & $-2.56 \mathrm{I}$ \\
\hline Centroid function (intermediate stage) & -1.353 \\
\hline Mean (threshold between stages) & -1.957 \\
\hline
\end{tabular}

\section{DISCUSSION}

We evaluated the performance of three classification schemes of secondary vegetation through the average of classification accuracy obtained by the LDA for each scheme. Our hypothesis was partially accepted, since only Scenario A showed a higher accuracy than the CONAMA scheme.

CONAMA classification uses several quantitative and qualitative variables for successional stage definition. The use of such variables can generate conflicting results, since, it is possible that each variable may indicate a different stage depending on the given area. Despite this, the three LDA based on the four structural and diversity variables indicated a relatively high average of classification accuracy of the stands from this scheme and solve the problem of different stage classification in the same area, since the variables were summarized in a discriminant function.

The Scenario A scheme showed a higher average of classification accuracy than the CONAMA. The adjustment of reference values adopted to differentiate each stage probably resulted in the highest mean of classification accuracy obtained among the other two schemes. However, this scheme also results in different stages for the same vegetation, according to the analyzed variable. Therefore, the construction of a predictive equation for this scheme becomes necessary, being able to circumvent this incoherence.

Scenario B scheme, in turn, presents a differentiated proposal based on ecological attributes of the dominant species (Siminski et al., 2013). However, its accuracy provided by the analysis was lower than the other two analyzed schemes. It is worth pointing out that, there is no ideal method for classifying stages 
of secondary succession in tropical rainforests (Lu et al., 2003; Chazdon, 2014).

Furthermore, it is assumed that a consistent method of differentiating successional stages must be: (I) simple and direct, (2) based on variables that can differentiate stages and reflect different structures and environmental influences, (3) able to be used in large scale and (4) potentially be applicable also by remote sensing techniques in large areas (Lu et al., 2003), despite the well-known obstacles to achieving the latter issue (Galvão et al., 2009). However, it is recommended to be usable on a large scale, each method should encompass only one vegetation type, since there is high variability among several structural and compositional parameters between forest types within the Atlantic Forest biome (Vibrans et al., 2012; Oliveira-Filho et al., 2014).

On the other hand, our predictive equation proposed here circumvents the indication of multiple stages for the same vegetation; in addition, it is based on easily obtainable variables and is developed on a systematic and spatially extended and unbiased dataset, from 203 stands. We must remember, however, that the predictive equation was developed based on standardized data, and if there are new observations to be classified by the equation, the data must be standardized as well.

The relationship of the variables to the $\mathrm{FI}$ of each LDA shows us certain patterns associated with a succession gradient in the generated functions. In almost all functions, considering all LDA runs, the mean DBH variable presented the greatest contribution to the models. Along with mean DBH, the variables AsyEst. Shannon and Pioneer.ind showed correlations that corroborate with the successional gradient, with an increase in mean tree diameter and number of species and reduction of the proportion of pioneer individuals as succession progresses. In fact, over time, tropical forests tend to accumulate more coexisting species and increase their structural complexity, reflecting the increase in estimated species richness and mean $\mathrm{DBH}$ range (Guariguata and Ostertag, 200I; van Breugel et al., 2006; Chazdon, 20I0; Silva et al., 2016). Likewise, the reduction of the proportion of pioneer individuals is expected during the ecological succession; these individuals are archetypal for disturbed or recently formed environments, adapted to the adverse soil and microclimatic conditions, thus, less frequent in later stages (Goodale et al., 20I2).

The use of the predictive equation (I) also provided us a threshold to distinguish the early and intermediate stages, indicating low values of tree density, estimated species richness and mean $\mathrm{DBH}$, and high proportion of pioneer individuals in early stage stands. It is worth mentioning that this is an approximate value, not definitively delimiting the limit between the two stages, but establishing a direction in favor of its discrimination.

\section{CONCLUSIONS}

Finally, given the problems associated with the current vegetation classification scheme proposed by CONAMA, there is great need to discuss the implications of these problems and a possible reformulation of the scheme itself, which could solve several of these inconsistencies. The equation developed here can overcome some of these inconsistencies, so we suggest the $\mathrm{DBH} \geq 10 \mathrm{~cm}$ as an inclusion criterion for sampling the variables used by the equation, since it was thus calibrated. It should be mentioned that the proposed equation was not tested with the use of remote sensing tools, but it is indicated to be used when there is availability of data obtained in phytosociological field surveys within the Subtropical Rainforest of Santa Catarina State. We recommend the use and testing of this equation in other areas under different conditions of degradation or conservation, aiming at its improvement.

\section{ACKNOWLEDGMENTS}

This study was supported by the scholarship granted by the Coordenação de Aperfeiçoamento de Pessoal do Nível Superior (CAPES) and the Fundação de Amparo à Pesquisa e Inovação de Santa Catarina (FAPESC) through the IFFSC project; and by the Universidade Regional de Blumenau (FURB) for the use of its facilities. Authors are grateful to Professor MSc. Marta Caetano (FURB Idiomas) for reviewing the English translation, and to MSc. Carlos Eduardo Schwartz for the provisioning of the study's area map.

\section{REFERENCES}

\section{ADDINSOFT. XLSTAT statistical and data analysis solution.} Boston, USA. 2019. Available at: (https://www.xlstat.com).

ANDREACCl, F; MARENZI, R. C. Avaliação da aplicação da Resolução CONAMA 04/94 na deinição dos estágios sucessionais de fragmentos florestais da Floresta Ombrófila Densa de Santa Catarina. Biotemas,v. 30, n. 4, p. II7-128, 2017

ARROYO-RODRÍGUEZ, V.; MELO, F. P. L.; MARTÍNEZRAMOS, M.; BONGERS, F.; CHAZDON, R. L.; MEAVE, J. A.; NORDEN, N.; SANTOS, B. A.; LEAL, I. R.; TABARELLI, $M$. Multiple successional pathways in human-modified tropical landscapes: new insights from forest succession , forest fragmentation and landscape ecology research. Biological Reviews, v. 92, p. 326-340, 2017. 
BOLIN, J. H.; FINCH, W. H. Supervised classification in the presence of misclassified training data: A Monte Carlo simulation study in the three-group case. Frontiers in Psychology, v. 5, p. I-10, 2014.

BRAZIL. Decreto $n^{\circ}$ 6.660, de 2 I de novembro de 2008. Diário Oficial da União, Poder Executivo, Brasília, DF, 24 dez. 2008. Seção I, p. I.

BRAZIL. Lei $\mathbf{n}^{\circ}$ I I.428 de 22 de dezembro de 2006. Diário Oficial da União, Poder Legislativo, Brasília, DF, 26 dez. 2006. Seção I, p. I.

CALMON, M.; BRANCALION, P. H. S.; PAESE, A; ARONSON, J.; CASTRO, P.; SILVA, S. C.; RODRIGUES, R. R. Emerging Threats and Opportunities for Large-Scale Ecological Restoration in the Atlantic Forest of Brazil. Restoration Ecology, v. 19, n. 2, p. 154-158, 201 I.

CHAO, A.; GOTELLI, N. J.; HSIEH, T. C.; SANDER, E. L.; MA, K. H.; COLWELL, R. K.; ELLISON, A. M. Rarefaction and extrapolation with Hill numbers: A framework for sampling and estimation in species diversity studies. Ecological Monographs, v. 84, n. I, p. 45-67, 2014.

CHAVENT, M.; LIQUET, B.; KUENTZ, V.; SARACCO, J. ClustOfVar: An R Package for the Clustering of Variables. Journal of Statistical Software, v. 50, p. I-I6, 2012.

CHAZDON, R. L. Second Growth: The promise of tropical forest regeneration in an age of deforestation. The University of Chicago Press, 2014. 449 p.

CHAZDON, R. L. Composition and Dynamics of Functional Groups of Trees During Tropical Forest Succession in Northeastern Costa Rica. Biotropica, v. 42, n. I, p. 31-40, 2010.

CHAZDON, R. L.; BRANCALION, P. H. S.; LAESTADIUS, L.; BENNETT-CURRY, A.; BUCKINGHAM, K.; KUMAR, C.; MOLL-ROCEK, J.; VIEIRA, I. C. G.; WILSON, S. J. When is a forest a forest? Forest concepts and definitions in the era of forest and landscape restoration. Ambio, v. 45, n. 5, p. 538-550, 2016

CHAZDON, R. L.; LETCHER, S. G.; VAN BREUGEL, M.; MARTÍNEZ-RAMOS, M.; BONGERS, F;; FINEGAN, $B$. Rates of change in tree communities of secondary Neotropical forests following major disturbances. Philosophical Transactions of the Royal Society B, v. 362, p. 273-289, 2007.

CHOKKALINGAM, U.; JONG, W. Secondary forest: a working definition and typology. International Forestry Review, v. 3, n. I, p. 19-26, 200I.

CONAMA - CONSELHO NACIONAL DO MEIO AMBIENTE. Resolução n.388, de 23 de fevereiro de 2007. Diário Oficial da União, n 38, 26 fev. 2007. Seção I, p. 63.

CONAMA - CONSELHO NACIONAL DO MEIO AMBIENTE. Resolução n.4, de 04 de maio de 1994. Diário Oficial da União, n I I4, I 7 jun. 1994. Seção I, p. 8877-8878.
DEAN, W. 1996. A ferro e a fogo: a história e a devastação da Mata Atlântica. Ist ed. Companhia das Letras, 1996. 484 p.

GALVÃO, L. S.; PONZONI, F. J.; SANTOS, J. R. Possibilities of discriminating tropical secondary succession in Amazônia using hyperspectral and multiangular CHRIS/PROBA data. International Journal of Applied Earth Observation and Geoinformation, v. I I, n. I, p. 8- |4, 2009.

GOODALE, U. M.; ASHTON, M. S.; BERLYN, G. P.; GREGOIRE, T. G.; SINGHAKUMARA, B. M. P.; TENNAKON, K. U. Disturbance and tropical pioneer species: Patterns of association across life history stages. Forest Ecology and Management, v. 277, p. 54-66, 2012.

GUARIGUATA, M. R.; OSTERTAG, R. Neotropical secondary forest succession: changes in structural and functional characteristics. Forest Ecology and Management, v. I48, p. |85-206, 200|

HOLDEN, J. E.; FINCH, W. H.; KELLEY, K. A. comparison of two-group classification methods. Educational and Psychological Measurement, v. 7I, n. 5, p. 870-90I, 20 I I.

HSIEH, T. C.; MA, K. H.; CHAO, A. iNEXT: an R package for rarefaction and extrapolation of species diversity (Hill numbers). Methods in Ecology and Evolution, v. 7, n. I2, p. I45I-|456, 2016.

ITTO - INTERNATIONAL TROPICAL TIMBER ORGANIZATION. ITTO guidelines for the restoration, management and rehabilitation of degraded and secondary tropical forests. ITTO Policy Development Series No. 13, 2002. $84 \mathrm{p}$.

LEBRIJA-TREjOS, E.; PÉREZ-GARCíA, E. A.; MEAVE, J. A.; POORTER, L.; BONGERS, F. Environmental changes during secondary succession in a tropical dry forest in Mexico. Journal of Tropical Ecology, v. 27, n. 05, p. 477-489, 201 I.

LEGENDRE, P.; LEGENDRE, L. Numerical ecology. 3rd ed. Elsevier, 2012. $1006 \mathrm{p}$.

LOHBECK, M.; POORTER, L.; MARTÍNEZ-RAMOS, M.; RODRIGUEZ-VELAZQUEZ, J.; VAN BREUGEL, M.; BONGERS, F. Changing drivers of species dominance during tropical forest succession. Functional Ecology, v. 28 , p. $1052-1058,2014$.

LU, D.; MAUSEL, P.; BRONDÍZIO, E.; MORAN, E. Classification of successional forest stages in the Brazilian Amazon basin. Forest Ecology and Management, v. I8I, p. 30I-312, 2003.

MELO, F. P. L.; ARROYO-RODRÍGUEZ, V.; FAHRIG, L.; MARTÍNEZ-RAMOS, M.; TABARELLI, M. On the hope for biodiversity-friendly tropical landscapes. Trends in Ecology \& Evolution, v. 28, n. 8, p. 46I-468, 2013.

MORSE, W. C.; SCHEDLBAUER, J. L.; SESNIE, S. E.; FINEGAN, B.; HARVEY, C. A.; HOLLENHORST, S. J.; KAVANAGH, K. L.; STOIAN, D.; WULFHORST, J. D. Consequences of Environmental Service Payments for Forest Retention and Recruitment in a Costa Rican Biological Corridor. Ecology and Society, v. I4, n. I, 23 p., 2009. 
MOTA, M. T.; BRESSANE, A.; ROVEDA, J. A. F; ROVEDA S. R. M. M. Classification of successional stages in atlantic forests: a methodological approach based on a fuzzy expert system. Ciência Florestal, v. 29, n. 2, p. 519-530, 2019.

NORDEN, N.; ANGARITA, H. A.; BONGERS, F; MARTÍNEZRAMOS, M.; CERDA, I. G.; VAN BREUGEL, M.; LEBRIJA-TREJOS, E.; MEAVE, J. A.; VANDERMEER, J.; WILLIAMSON, B. G.; FINEGAN, B.; MESQUITA, R.; CHAZDON, R. L. Successional dynamics in Neotropical forests are as uncertain as they are predictable. Proceedings of the National Academy of Science, v. II2, n. 26, p. 80I3-80I8, 2015.

OLDEN, J. D. Biotic homogenization: a new research agenda for conservation biogeography. Journal of Biogeography, v. 33, p. 2027-2039, 2006.

OLDEN, J. D.; POFF, N. L.; DOUGLAS, M. R.; DOUGLAS, M. E.; FAUSCH, K. D. Ecological and evolutionary consequences of biotic homogenization. Trends in Ecology \& Evolution, v. 19, n. I, p. 18-24, 2004.

OLIVEIRA-FILHO, A. T. Classificação das fitofisionomias da América do Sul cisandina tropical e subtropical: proposta de um novo sistema—prático e flexível—ou uma injeção a mais de caos? Rodriguésia, v. 60, p. 237-258, 2009.

OLIVEIRA-FILHO, A. T.; BUDKE, J. C.; JARENKOW, J. A.; EISENLOHR, P. V.; NEVES, D. R. M. Delving into the variations in tree species composition and richness across South American subtropical Atlantic and Pampean forests. Journal of Plant Ecology, v. 8, n. 3, p. 242-260, 2014

PENG, S. L.; HOU, Y. P.; CHEN, B. M. Establishment of Markov successional model and its application for forest restoration reference in Southern China. Ecological Modelling, v. 221 , n. 9, p. 1317-1324, 2010.

PICKET, S. T. A.; PARKER, V. T.; FIEDLER, P. L. The New Paradigm in Ecology: Implications for Conservation Biology Above the Species Level. In: FIEDLER, P. L.; JAIN, S. K. Conservation Biology: the theory and practice of nature conservation preservation and management. Chapman and Hall, 1992. p. 65-88.

PICKETT, S. T. A.; CADENASSO, M. L.; MEINERS, S. J. Ever since Clements: From succession to vegetation dynamics and understanding to intervention. Applied Vegetation Science, v. I2, n. I, p. 9-21, 2009.

PRACH, K.; WALKER, L. R. Four opportunities for studies of ecological succession. Trends in Ecology \& Evolution, v. 26, n. 3, p. II9-123, 2011 .

R CORE TEAM. R: A Language and Environment for Statistical Computing. R Foundation for Statistical Computing, 2018. Available at: (https://www.R-project.org/).

REZENDE, C. L.; SCARANO, F. R.; ASSAD, E. D.; JOLY, C. A.; METZGER, J. P.; STRASSBURG, B. B. N.; TABARELLI, M.; FONSECA, G. A.; MITTERMEIER, R. A. From hotspot to hopespot: An opportunity for the Brazilian Atlantic Forest. Perspectives in Ecology and Conservation, v. 16, n. 12, p. 208-2|4, 2018.
RIBEIRO, M. C.; METZGER, J. P.; MARTENSEN, A. C.; PONZONI, F. J.; HIROTA, M. M. The Brazilian Atlantic Forest: How much is left, and how is the remaining forest distributed? Implications for conservation. Biological Conservation, v. I42, n. 6, p. II4I-II53, 2009.

ROMÁN-DAÑOBEYTIA, F. J.; LEVY-TACHER, S. I.; MACARIOMENDOZA, P.; ZÚÑIGA-MORALES, J. Redefining secondary forests in the mexican forest code: Implications for management, restoration, and conservation. Forests, v. 5, n. 5, p. 978-99।, 2014.

SCARANO, F. R.; CEOTTO, P. Brazilian Atlantic forest: impact, vulnerability, and adaptation to climate change. Biodiversity and Conservation, v. 24, n. 9, p. 2319233I, 2015

SILVA, C. V. J.; SANTOS, J. R.; GALVÃO, L. S.; SILVA, R. D.; MOURA, Y. M. Floristic and structure of an Amazonian primary forest and a chronosequence of secondary succession. Acta Amazonica, v. 46, n. 2, p. 133-150, 2016.

SIMINSKI, A.; FANTINI, A. C. A Mata Atlântica cede lugar a outros usos da terra em Santa Catarina, Brasil. Biotemas, v. 23 , n. 2 , p. $51-59,2010$

SIMINSKI, A.; FANTINI, A. C. Classificação da Mata Atlântica do Litoral Catarinense em Estádios Sucessionais: Ajustando a Lei ao Ecossistema. Floresta e Ambiente, v. I I, n. 2, p. 20-25, 2004.

SIMINSKI, A.; FANTINI, A. C.; REIS, M. S. Classificação da vegetação secundária em estágios de regeneração da Mata Atlântica em Santa Catarina. Ciência Florestal, v. 23, n. 3, p. 369-378, 2013.

SIMINSKI, A.; MANTOVANI, M.; REIS, M. S.; FANTINI, A. C. Sucessão florestal secundária no município de São Pedro de Alcântara, litoreal de Santa Catarina: estrutura e diversidade. Ciência Florestal, v. I4, n. I, p. 21-33, 2004.

SOLAR, R. R. C.; BARLOW, J.; FERREIRA, J.; BERENGUER, E.; LEES, A. C.; THOMSON, J. R.; LOUZADA, J.; MAUÉS, M.; MOURA, N. G.; OLIVEIRA, V. H. F.; CHAUL, J. C. M.; SCHOEREDER, J. H.; VIEIRA, I. C. G.; NALLY, R. M.; GARDNER, T. A. How pervasive is biotic homogenization in human-modified tropical forest landscapes?. Ecology Letters, v. 18, p. II08-III8, 2015.

VAN BREUGEL, M.; HALL, J. S.; CRAVEN, D.; BAILON, M.; HERNANDEZ, A; ABBENE, M.; VAN BREUGEL, P. Succession of Ephemeral Secondary Forests and Their Limited Role for the Conservation of Floristic Diversity in a Human-Modified Tropical Landscape. PLoS One, v. 8, n. 12, e82433, 2013.

VAN BREUGEL, M.; MARTÍNEZ-RAMOS, M.; BONGERS, F. Community dynamics during early secondary succession in Mexican tropical rain forests. Journal of Tropical Ecology, v. 22, n. 6, p. 663-674, 2006. 
VIBRANS, A. C.; SEVEGNANI, L.; GASPER, A. L.; LINGNER, D. V. Inventário florístico florestal de Santa Catarina: Floresta Ombrófila Densa. Vol. 4. Edifurb, 2013. 574 p.

VIBRANS, A. C.; SEVEGNANI, L.; GASPER, A. L.; LINGNER,

D. V. Inventário florístico florestal de Santa Catarina: Diversidade e conservação dos remanescentes florestais. Vol. I. Edifurb, 20I2. 342 p.
VIBRANS, A. C.; SEVEGNANI, L.; LINGNER, D. V.; GASPER, A. L.; SABBAGH, S. Inventário florístico florestal de Santa Catarina (IFFSC): aspectos metodológicos e operarionais. Pesquisa Florestal Brasileira, v. 30, n. 64, p. 29I-302, 2010.

ZAR, J. H. Biostatistical analysis. 5th ed. Prentice Hall. 2010. $944 \mathrm{p}$. 